\title{
Review \\ The Role of Plant Growth-Promoting Rhizobacteria (PGPR) in Mitigating Plant's Environmental Stresses
}

\author{
Marco Vocciante ${ }^{1, *(\mathbb{D}}$, Martina Grifoni ${ }^{2} \mathbb{D}$, Danilo Fusini ${ }^{3} \mathbb{D}$, Gianniantonio Petruzzelli ${ }^{2}$ and Elisabetta Franchi $^{3}(\mathbb{D}$ \\ 1 Department of Chemistry and Industrial Chemistry, Università degli Studi di Genova, Via Dodecaneso 31, \\ 16146 Genova, Italy \\ 2 Institute of Research on Terrestrial Ecosystems, National Council of Research, Via Moruzzi 1, 56124 Pisa, Italy; \\ martinagrifoni@santannapisa.it (M.G.); gianniantonio.petruzzelli@cnr.it (G.P.) \\ 3 Eni S.p.A., Decarbonization \& Environmental R\&D, Via Maritano 26, 20097 San Donato Mil.se, Italy; \\ danilo.fusini@eni.com (D.F.); elisabetta.franchi@eni.com (E.F.) \\ * Correspondence: marco.vocciante@unige.it
}

Citation: Vocciante, M.; Grifoni, M.; Fusini, D.; Petruzzelli, G.; Franchi, E. The Role of Plant Growth-Promoting Rhizobacteria (PGPR) in Mitigating Plant's Environmental Stresses. Appl. Sci. 2022, 12, 1231. https://doi.org/ 10.3390/app12031231

Academic Editor: Jose Antonio

Rodriguez Martin

Received: 28 December 2021

Accepted: 24 January 2022

Published: 25 January 2022

Publisher's Note: MDPI stays neutral with regard to jurisdictional claims in published maps and institutional affiliations.

Copyright: (c) 2022 by the authors. Licensee MDPI, Basel, Switzerland. This article is an open access article distributed under the terms and conditions of the Creative Commons Attribution (CC BY) license (https:// creativecommons.org/licenses/by/ $4.0 /)$.

\begin{abstract}
Phytoremediation is a cost-effective and sustainable technology used to clean up pollutants from soils and waters through the use of plant species. Indeed, plants are naturally capable of absorbing metals and degrading organic molecules. However, in several cases, the presence of contaminants causes plant suffering and limited growth. In such situations, thanks to the production of specific root exudates, plants can engage the most suitable bacteria able to support their growth according to the particular environmental stress. These plant growth-promoting rhizobacteria (PGPR) may facilitate plant growth and development with several beneficial effects, even more evident when plants are grown in critical environmental conditions, such as the presence of toxic contaminants. For instance, PGPR may alleviate metal phytotoxicity by altering metal bioavailability in soil and increasing metal translocation within the plant. Since many of the PGPR are also hydrocarbon oxidizers, they are also able to support and enhance plant biodegradation activity. Besides, PGPR in agriculture can be an excellent support to counter the devastating effects of abiotic stress, such as excessive salinity and drought, replacing expensive inorganic fertilizers that hurt the environment. A better and in-depth understanding of the function and interactions of plants and associated microorganisms directly in the matrix of interest, especially in the presence of persistent contamination, could provide new opportunities for phytoremediation.
\end{abstract}

Keywords: phytoremediation; rhizosphere; plant-microbe interaction; metal uptake; hydrocarbon rhizodegradation; marginal soils; drought; salinity

\section{Introduction}

Although the soil is a valuable and non-renewable ecological system, it has always been subject to widespread degradation due to anthropic activities. Process industry [1], transport, urban sprawl, agriculture, and illegal dumping or landfill [2] without adequate resource recovery [3] represent just some of the many causes of direct release or indirect deposition of organic and inorganic pollutants (including heavy metals, mineral oils, and polycyclic aromatic hydrocarbons) into the soil, with hazardous effects on the environment and human health [4]. The remediation of contaminated soils and sites is, therefore, a significant step in the protection of the environment and living organisms and must be included in the broader multidisciplinary scenario of a strategic green transition.

Nowadays, several approaches have been developed to deal with contaminated water [5-8] and soils $[9,10]$, making the optimal selection a tricky yet crucial phase for the success of the remediation [11,12].

However, remediation activities inevitably involve a certain consumption of raw materials and energy, also relying in many cases on the use of impacting chemical products or processes. This could compromise the sustainability of the intervention or even invalidate its 
positive aspects when performed to remove contamination without any consideration of the side effects, thus further impacting an already compromised environmental situation [13,14].

In order to avoid this, more and more efforts are being made to replace environmentally unsound technologies with green and sustainable solutions [15], aiming not only at eliminating or reducing contamination but also at minimizing environmental impact [16].

Phytoremediation is a solar-driven, cost-effective, and fully sustainable $[17,18]$ soil remediation technology based on the ability of plants to capture, extract, accumulate, or degrade a wide range of inorganic (heavy metals, radionuclides) and organic (hydrocarbons, polycyclic aromatic hydrocarbons, pesticides, pharmaceuticals) soil contaminants [19-21]. Besides, biomass from phytoremediation can be converted into bioenergy and also support biological diversity and stabilize the soil. In addition, the combined use with other solutions to further increase the overall sustainability is under investigation [22].

Nevertheless, some intrinsic factors due to the high variability of biological systems [23], including relatively long intervention times and the uncertainty about the achievable results, make phytoremediation still little appreciated. Indeed, the effectiveness of the treatment strongly depends on the selected species [24]. It is also necessary to consider numerous other aspects, such as the characteristics of the contamination, the properties of the soil, and, above all, the fundamental interaction of the plant microorganisms [25].

Increasing evidence suggests that this latter aspect strongly determines phytoremediation achievement, which goes well beyond the activity of the individual microorganism, on which many of the works on phytoremediation focus. Thus, integrated studies of the plant microbiome are essential, because understanding how the host plant organizes its beneficial microbiome - thousands of degrading microbial taxa [26] — in various stressful situations due to the presence of contaminants is the key to effectively achieving the remediation objectives.

Root exudates play a crucial role in the composition of the microbial community of the rhizosphere [27]. Indeed, plants secrete specific molecules depending on different contaminants, thus attracting microorganisms that have catabolic pathways suitable for the degradation of those particular molecules [28]. It is hypothesized that the colonization of roots by specific rhizobacteria could begin through a first selection related to the characteristics of the bacterial cell wall followed by a second more stringent and specific selection for certain groups of microorganisms [29]. Recent studies show, in Zea mays and Solanum lycopersicum, the secretion of specific molecules that attract beneficial bacteria active against phytopathogens [30-32]. These exudates secreted by plants show different specificities depending on the root portion. Micro-environments have different chemical-physical characteristics associated with distinct microbial communities [33].

These and numerous other factors, including the state of the plant and the presence of other vegetable species [34], make the rhizosphere one of the most complex ecosystems.

Meta-transcriptomic analyses revealed the presence of many specific catabolic genes [35] in the rhizospheric microbiome of contaminated soils, suggesting that the plant selects the most suitable microorganisms for that particular environmental condition. However, how this selection takes place is still unclear, as these various shreds of experimental evidence do not explain the mechanism by which the host plant can "choose" and select the most suitable degrading microbiome among the many possible options.

Some studies attribute this selection to the co-evolution of the latter with the host plant through vertical gene transfer or degradative pathways acquired from seeds [36]. However, this would not explain how plants of the same species grown in different contaminated soils exhibit different microbial communities with different degrading activities. Indeed, plants select most of the degradative and growth-promoting microorganisms (PGPR) from the rhizospheric soil $[23,37]$ by producing specific exudates in the presence of contaminating molecules to favor the microbiome having the necessary enzymes [38]. Another recent study concerning a remediation intervention of sediment contaminated by hydrocarbons shows how the plants have exerted a species-specific pressure on the structure of the rhizosphere's microbial communities, highlighting its selectivity. These results also show that bioaugmentation caused a significant change in microbial communities. Still, the 
presence of plants in contaminated sediments certainly had a much stronger influence on the structure of the microbiome [39].

An intense competition takes place in the rhizosphere of contaminated soil, where microorganisms able to use the specific radical exudates and metabolize contaminating molecules will prevail [40]. The concept of competition as a driving force [23] refers to original studies of Grime, which hypothesizes that the evolution of plants is associated with three primary strategies, including competition [41].

In an attempt to explain the formation of a beneficial microbiome at the level of the rhizosphere of contaminated soil, Thijs and collaborators [23], also according to previous studies [40], propose a model that relates this development to the abundance of root exudates, and the efficiency of the microbiota formed to the amount of degrading genes at the beginning of plant development or to the establishment of a sort of vertical transmission.

More specifically, the bacteria associated with plants are not limited to the rhizospheric, but include endophytic (inside the roots) and phyllospheric (on the surface of the leaves) bacteria [42]. Plants need to establish intimate relationships with the surrounding environment due to their sessile nature, so they have co-evolved with microorganisms to exploit this symbiosis, which allows for greater plant survival and treatment results in contaminated sites [43] by creating a symbiotic system in response to abiotic stress (Figure 1), defined as a holobiont [44]. The principal abiotic stresses that plants undergo are schematized in Figure 1: organic and inorganic contaminants, salinity, and drought, which are often associated. The reaction of the plants is assisted by the rhizospheric microorganisms that put in place protective mechanisms. Furthermore, plants under prolonged stress conditions become much more susceptible to attack by pathogens, thus adding biotic stress. The beneficial molecules and the activities described in the figure interact with the roots, creating a support network for plant survival. This positive effect on the adaptation of host plants to critical soil conditions by bacteria is not limited to organic contamination, also modifying the bioavailability of metals in the soil and increasing the translocation of metals within the plant [45].

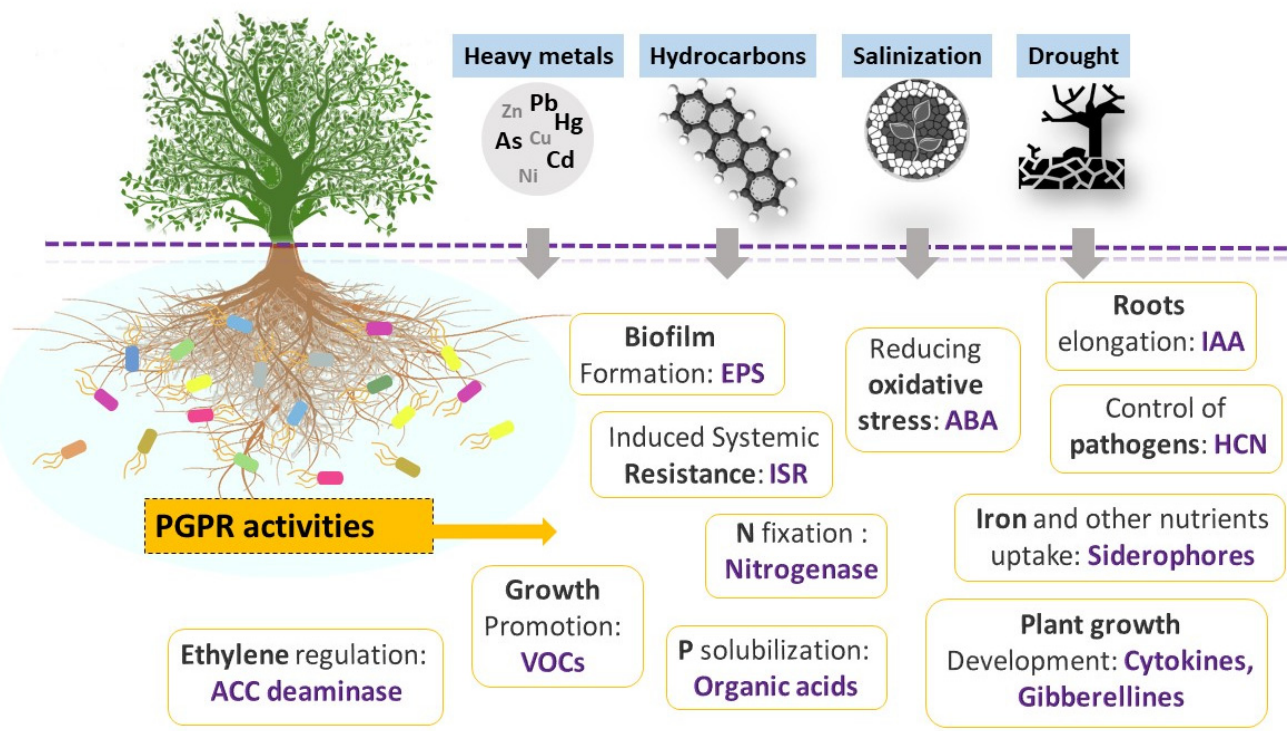

Figure 1. The sophisticated and efficient network of functional interactions created by PGPR to support plants' health and performances in response to adverse environmental conditions and abiotic stresses. Abbreviations: EPS (exopolysaccarides); ABA (abscisic acid); IAA (indol2-3-acetic acid); HCN (hydrogen cyanide); VOCs (volatile organic compounds); ACC (1-aminocyclopropane-1carboxylic acid).

\section{Properties and Potential of Plant Growth-Promoting Rhizobacteria (PGPR)}

Plant growth-promoting bacteria (PGPR) are soil bacteria living in the rhizosphere which, through the secretion of various regulatory molecules, are involved in promoting 
plant growth and development. They can be found associated with the roots (rhizosphere), with the leaves (phyllosphere), or within the plant (endosphere). The endophytes (PGPE) are generally the most effective in supporting growth; being inside the plant tissues, they can communicate with the host plant and exert their beneficial effect much more efficiently [46]. Furthermore, the PGPE, protected from the external environment, are much less subject to the soil's frequent chemical-physical biotic and abiotic variations. Endophytic bacteria come from the rhizosphere ecosystem surrounding the roots and penetrate into plant tissues mainly by using natural fissures created in the roots during growth. The exudates and radical metabolites produced by plants represent an essential resource capable of selecting and attracting the most beneficial bacteria [47]. The profitable action of the bacteria associated with plants is mainly expressed by directly promoting the absorption of nutrients through the modulation of the levels of plant hormones. The most important and studied direct mechanisms are nitrogen fixation [48], the solubilization of inorganic phosphate [49], auxins (in particular 3-indole acetic acid, IAA [50]), cytokinins, and gibberellins [51]; the enzyme 1-aminocyclopropane-1-carboxylate (ACC) deaminase [52] and the production of siderophore molecules [53] (Figure 2). Instead, indirect mechanisms are defined as the inhibitory activities when the growth-promoting bacteria hinder the negative effect of pathogenic organisms (biotic stress). Some of the most common indirect mechanisms are the production of hydrogen cyanide, antibiotics, and enzymes capable of attacking and degrading the cell wall of pathogens [54].

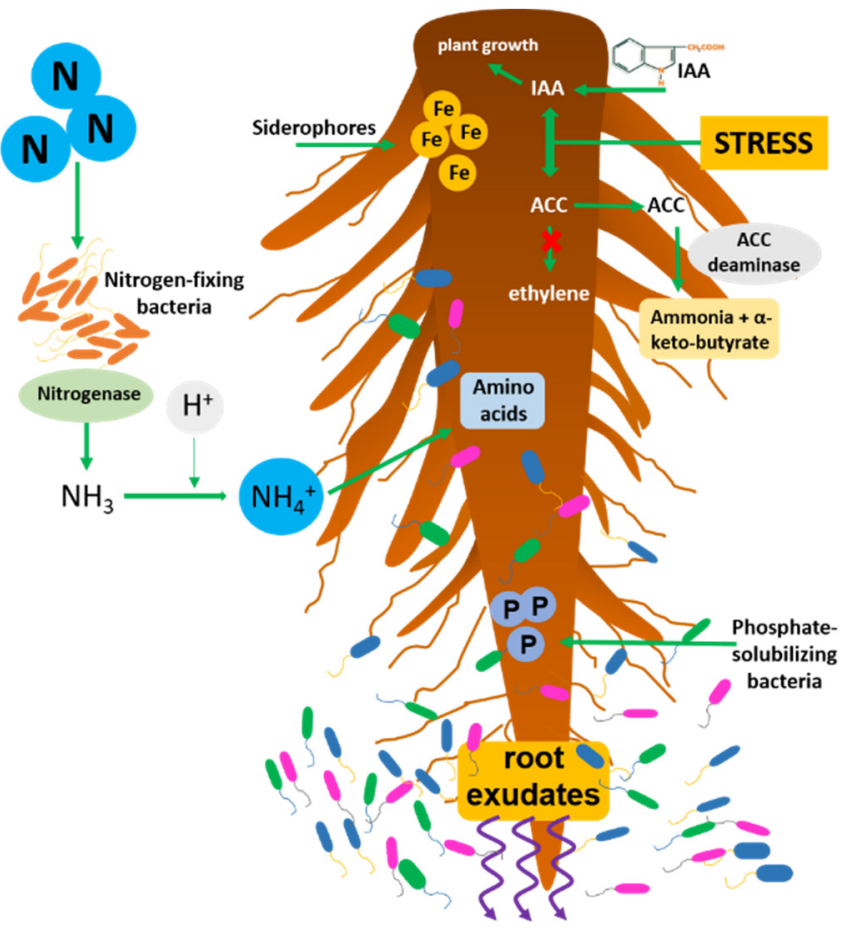

Figure 2. Simplified scheme of the main activities of PGPR and their interactions with the root system; nitrogen-fixation, phosphate solubilization, iron uptake by siderophores, ACC deaminase activity lowering ethylene levels, IAA production stimulating plant cell growth.

\subsection{Siderophores}

Since iron $(\mathrm{Fe})$ is often present in the soil as a trivalent $\mathrm{Fe}^{3+}$ insoluble hydroxide, plants do not easily assimilate it. Small siderophore molecules are produced and secreted by bacteria (and fungi and plants) that facilitate iron absorption in the plant cell. From the chemical point of view, there are four chemical types of siderophores (catecholates, phenolates, hydroxamates, and carboxylates), but mixtures of the various types are also very common [55]. Siderophores produced by PGPR have a very high affinity for iron and can therefore se- 
quester even small amounts of that element [56]. Bacterial siderophores can also increase metals bioavailability, favoring their uptake by plants through phytoextraction $[57,58]$.

\subsection{Phosphate Solubilization}

Phosphorus $(\mathrm{P})$ is an essential element for plant growth but is scarcely available in the soil. P occurs naturally in organic (Po, average 50\%) and inorganic (Pi, average $50 \%$ ) forms [59]. They are both not very soluble (generally no more than $5 \%$ ) and therefore cannot be absorbed by the roots. The action that soil bacteria can carry out is fundamental for the solubilization and mineralization of $\mathrm{P}$ [60]. Plants can absorb monobasic $\left(\mathrm{H}_{2} \mathrm{PO}^{-4}\right)$ and dibasic $\left(\mathrm{HPO}^{-24}\right)$ ions. The solubilization of Pi occurs mainly with the decrease of $\mathrm{pH}$ in the soil due to the production of low molecular weight organic acids. The mineralization of organic phosphorus, on the other hand, occurs through the hydrolysis of phosphoric esters by phosphatase [49].

The availability of sufficient quantities of $\mathrm{P}$ following the activity of phosphate solubilizing bacteria (PSB) could lead to a significant decrease in the use of chemical fertilizers. The beneficial effect on plants also promotes greater efficiency of phytoextraction or phytostabilization in the presence of heavy metals.

\subsection{Nitrogen Fixation}

Nitrogen $(\mathrm{N})$ is also an essential element for plant growth. Although atmospheric nitrogen is present in high quantities (78\%), it is not found in the form available for absorption by the roots from the soil. This is mainly due to the biological nitrogen fixation (BNF) mediated by an enzymatic reaction catalyzed by the enzyme nitrogenase, transforming the atmospheric $\mathrm{N}_{2}$ into ammonia $\left(\mathrm{NH}_{3}\right)$. BNF can be exerted by bacteria living in symbiotic association with legumes or higher plants, such as alder (Alnus spp.), feeding the associated nitrogen-fixing bacteria, or it can also occur in a non-symbiotic relationship through heterotrophic or autotrophic bacteria free-living in the rhizosphere [61,62]. Among the free-living (non-symbiotic) bacteria, we remember the cyanobacteria (or blue-green algae), Anabaena and Nostoc, and genera, such as Azotobacter, Beijerinckia, and Clostridium. Among the symbiotic bacteria, there are the genera Rhizobium, associated with leguminous plants; Frankia, associated with some dicotyledonous species; and some Azospirillum, associated with grasses $[48,63]$. In Leguminosae, colonization and subsequent invasion of rhizobia leading to active nodules containing symbiotic nitrogen-fixing bacteria can occur through root hairs or wounds in root tissue or even through intact plant cells [64].

\subsection{Auxins, Cytokinins, Gibberellins}

The phytohormone IAA is the most common auxin among plant-associated bacteria and play a central role in plant-bacterial interactions [65]. The main beneficial effect is root augmentation, especially root hairs and secondary roots, which consequently leads to an increase in root exudates; therefore, the production of IAA is certainly one of the most important mechanisms that favor plant growth [66]. The greater the root surface, the better the absorption of minerals from the soil. It also increases the valuable surface for the colonization of bacteria attracted by plant metabolites.

Cytokinins play a central role in developing the vascular system, in embryogenesis, in the formation of nodules, and in response to environmental changes [67]. Gibberellins are involved in the transport of metabolites in the formation of chloroplasts, leaf senescence, cell division, and stem morphogenesis [68]. While the biosynthetic pathways of gibberellins in plants and fungi have been thoroughly investigated and elucidated, little has been discovered about the biosynthesis of these enzymes in bacteria. Recent studies [69] hypothesize that bacteria have developed an independent biosynthetic pathway for the production of gibberellins. 


\subsection{ACC Deaminase}

The occurrence of the ACC deaminase enzyme is another important direct mechanism of plant growth promotion [70]. The action of this enzyme is carried out with the inactivation of the ethylene precursor ACC, generating ammonia and alpha-ketobutyrate. High levels of ethylene can inhibit plant growth and even kill them. During saline or other environmental stress, ACC synthase and ACC oxidase activity increase ethylene synthesized by the plant. Therefore, the bacterial enzyme ACC deaminase helps plants decrease the negative effects of stress by facilitating adaptation and survival [71].

It is also interesting to underline the interaction between the activity of the ACC deaminase enzyme and the action of auxin IAA because the latter can activate the transcription of the ACC synthase enzyme, which leads to an increase in ethylene levels. The increase in the level of ethylene leads to an inhibitory response to the production of IAA, which inhibits the positive effect on plant growth. However, the presence of the ACC deaminase enzyme, which lowers the level of ethylene, counteracts the inhibition, as mentioned earlier. Many of the PGPB recognized to positively affect metals contamination in constructed wetlands can synthesize both ACC deaminase and IAA [72].

\subsection{Indirect Mechanisms}

The mechanisms that indirectly promote plant growth counteract pathogens' detrimental effects [73]. Bacteria that perform this can produce antibiotics [74] or lytic enzymes degrading the cell wall. In addition to making these harmful substances for phytopathogens, PGPR can act by contending with them for the same nutrients and root colonization sites $[75,76]$, reducing the proliferation of pathogens or even producing small amounts of hydrogen cyanide $(\mathrm{HCN})$. $\mathrm{HCN}$ often collaborates with other biocontrol mechanisms that PGPR implement [54].

\section{Effectiveness of PGPR in Hydrocarbons and Heavy Metals Contaminated Soils}

PGPR can have wildly different levels of effectiveness in aiding remediation depending on many of the biological and chemical properties of the contaminated soil, ranging from presence and ratio of nutrients (e.g., $\mathrm{N}$ and $\mathrm{P}$, competition and predation, mutation, horizontal genes transfer), to metal ions availability, quantity, and type of contaminant, and moisture. High oxygen concentration can generally help decompose organic pollutants since most degrading pathways oxidase these chemicals; it is, however, mandatory to remember that many microorganisms cannot tolerate even low oxygen levels. The addition of this nutrient could potentially kill beneficial organisms. It is also hard to overestimate the effect of temperature and $\mathrm{pH}$ in determining an organism survival and reproductive rates, enzymes activity, and metabolic processes, as well as the bioavailability of contaminants and their chemical form [77]. For this reason, many sites polluted by hydrocarbon are added with nutrients (nitrogen, phosphorus, potassium, etc.) and high-energy electron acceptors (especially oxygen). Some of these chemicals can be provided by plants through roots exudates. This sets up a positive feedback loop, where plants allow the presence and growth of PGPR and bacteria render the soil less toxic and aid plant growth through several mechanisms [43].

It is important to remember that petroleum hydrocarbons (PHC) are not degraded with the same efficiency. The microorganisms begin to degrade the simpler hydrocarbons (n-alkanes) first, followed by the branched ones, cyclic alkanes, to finally arrive at the most complex hydrocarbons (polyaromatics hydrocarbons PAH) [43,78]. This means that molecules, such as naphthalene, phenanthrene, and pyrene are not easy to get rid of through biodegradation.

For such molecules, the presence of plants (or phytoremediation) might provide a significant difference in degradation rates. For example, in a study conducted to observe the phytoremediation capability of Trigonella foenum-graceum and Brassica juncea in the presence of PGPR on saline soil contaminated with $400 \mathrm{mg} / \mathrm{kg}$ of phenanthrene, it was possible to reach a $99 \%$ of dissipation rate in 60 days [79]. 
However, many organic compounds can be highly toxic for plants, so much so that it could undermine the success of the phytoremediation. Bacteria can significantly decrease the harmful effect of many such compounds. They achieve this effect through nitrogen fixation and mobilization of nutrients, prevention of ethylene production (ACC deaminase activity), and the direct production of phytohormones. This is why it is important to create interaction between PGPR and the host plant [80] since they can suppress the inhibition of germination caused by contaminants [81]. It is, however, important to distinguish between two types of root-associated bacteria: those who remain close to or on the root surface are referred to as rhizospheric bacteria, while those that manage to enter the root tissue are called endophytes. Since the latter are protected by the root, they can influence the host plant more directly while living in a homeostatic environment, generally providing better support for degrading contaminants [82,83].

Organic compounds are not the only toxic pollutants for plants; heavy metals can cause massive changes in soil's chemical-physical proprieties.

Plants need to produce a homeostatic network to control absorption, accumulation, and the oxidative stress that derives from heavy metals presence [84]; to do this, plants trigger many physiological and molecular mechanisms, such as active transport of ions into cell vacuoles, sequestration of metal-siderophore complexes, and production of root exudates to solubilize mineral nutrient and stimulate microbial growth $[57,85]$.

Although metals are often present as insoluble salt and need to be mobilized by chemicals, such as EDTA (Ethylenediaminetetraacetic acid) and EDDS (Ethylenediamine$\mathrm{N}, \mathrm{N}$-disuccinic acid), PGPR can enhance phytoextraction by reducing the toxicity of heavy metals in plants through helping control absorption, possible accumulation, or detoxification of heavy metals [85].

Those microorganisms can tolerate a high concentration of metals and can modify metal bioavailability by releasing chelants, such as organic acids and siderophores, and changing the soil $\mathrm{pH}$ [57]. Several studies report the isolation of microbial strains that effectively support phytoextraction or phytostabilization of various heavy metals. Among these, for example, Bacillus pumilus [57], Rhodococcus erythropolis [86], Bradyrhizobium sp. [87], Ralstonia eutropha, and Chryseobacterium humi [88].

Some PGPR, such as Sinorhizobium meliloti (a metal resistant rhizobium), can also, while co-inoculated with other PGPR, reduce the oxidative stress that some metals, such as $\mathrm{Cu}$, cause to plants; this can greatly increase the metal intake during phytoextraction [89]. This effect may be attributed to the ability of rhizobium and PGPR to provide balanced nutrition to the host plant [90].

The inoculated plants had considerably lower ROS (reactive oxygen species) accumulation and a higher level of antioxidants enzymes, specifically peroxidase (POD), superoxide dismutase (SOD), catalase (CAT), and ascorbate peroxidase (APX). Other studies seem to align with this result even when considering multiple growth parameters: plant biomass, the fluorescence of photosynthetic pigments, number of leaves, and shoot and root length [91,92].

However, some studies suggest that by combining the effect of both PGPR and a chelating agent, it is possible to achieve the best phytoextraction result [93-96]. In the first study, the $\mathrm{Cu}$ concentration in the shoots was up to 4.2 times higher in plants that were both inoculated with PGPR and treated with EDTA compared to the control. It is important to note that EDTA alone was unable to increase the biomass, likely due to the increased bioavailability of the contaminant. This effect is observable even at a high contaminant concentration [97].

\section{PGPR to Face Salinization and Drought in Marginal Soils}

\subsection{Facing the Abiotic Stresses}

The action of PGPR during abiotic stress situations caused by drought, salinity, soil alkalization, or harmful chemicals is critical for adequate plant growth [98]. Protracted drought conditions induce PGPR to secrete molecules (i.e., phytohormones, osmolytes, extracellular polymers, and antioxidants) which can induce structural and morpholog- 
ical changes in the roots. These modifications increase tolerance to stress, favoring an appropriate development of the root system, thus allowing the plants to adapt to adverse environmental conditions. A well developed and branched root system is crucial as, in drought situations, the root tips can reach the deeper soil layers, absorbing the necessary water and nutrients [99].

\subsection{Drought and Salinity Pressure}

Soil microorganisms can modify their membrane structure and thus counteract the scarcity of humidity. For example, they can produce polysaccharides. Thanks to their hygroscopicity, they can trap and hold water molecules in their structure, helping maintain the acceptable moisture content in the microenvironment surrounding them [100]. A recent study showed that Bacillus subtilis and Azotobacter brasilense strains, isolated from an arid region of Pakistan, could produce high amounts of EPS. The inoculation into wheat seedlings, both individually and in a consortium, led to a significant increase in plants osmotic potential, water potential, and chlorophyll content [101].

Unfortunately, due to climate changes, the phenomenon of drought is constantly increasing and represents one of the most fearful abiotic stresses. It modifies the physiology and morphology of plants by reducing the diffusion within the tissues of water-soluble nutrients, such as sulphates, nitrates, calcium, magnesium, etc. [102]. PGPR can support plants in counteracting the detrimental effects of drought stress. Experimental evidence shows how some endophytic microorganisms can mitigate water stress even in plants other than those from which they have been isolated.

This evidence indicates that the interaction of PGPR is not specific, and this could facilitate mitigation interventions. The continuous worsening of climate change is modifying the global geography, with a fast transformation of many agricultural areas into marginal soils inappropriate for the life of populations, making the role of PGPR progressively more and more critical.

Taking advantage of plant-microbe interactions that can positively impact the response of plants to drought and, in general, to all abiotic stresses is a compelling strategy. The roots that show a high structural and morphological plasticity are the first to undertake the chemical-physical modifications of the soil in the presence of abiotic stress. Drought leads to significant changes in the phospholipid composition of the root membrane. Under water stress conditions, many PGPR produce the hormone ABA capable of regulating plant cell dehydration by controlling stomatal closure, decreasing leaf transpiration, and stress signal transduction [103]. Still, the action of PGPR, which increases the elasticity of the root membranes, can respond to these adverse effects on the root and allow the new roots to penetrate deeper into the soil to reach basins of water [104,105]. PGPR activity in drought conditions is also represented by the storage of solutes within plant cells to act on cellular osmotic regulation. The substances generally accumulated are amino acids, such as proline, glycine, phenylalanine, organic acids, sugars, and inorganic ions, which can cooperate to protect plants from possible oxidative damage [106].

The other abiotic factor that is particularly damaging and often associated with drought is the salinization of soils, which is an ever-increasing global threat.

The high salt concentration often harms the soil, particularly the organic material decomposition, nitrification, denitrification, microbial activity, and the biodiversity [107]. Removing excess salt from soils by physical and chemical methods is a time-consuming and costly operation, unsustainable and ineffective with high salt concentrations [108]. Salt stress can cause a drastic reduction in the productivity of various crops and mainly fruit crops, such as the species of the genus Prunus, which are considered very sensitive to salt. To prevent, at least in part, these conditions that may limit the normal development of these fruit trees, one of the agronomic strategies successfully adopted is that which uses rootstocks tolerant to biotic and abiotic factors [109]. The phenomenon of salinization concerns all the salts which, if in excess, can cause severe damage, but they are mainly sodium chloride $(\mathrm{NaCl})$, sodium sulphate $\left(\mathrm{Na}_{2} \mathrm{SO}_{4}\right)$, magnesium sulphate $\left(\mathrm{MgSO}_{4}\right)$, and 
magnesium chloride $\left(\mathrm{MgCl}_{2}\right)$; however, $\mathrm{NaCl}$ is certainly the most critical one. Excessive salinity modifies the biochemical and physiological processes of the plant, and photosynthetic efficiency can also be significantly altered [110]. Numerous soil microorganisms able to tolerate the presence of salt even at high concentrations have been identified and characterized. We describe bacteria belonging mainly to the genera Bacillus, Pseudomonas, Agrobacterium, Enterobacter, Klebsiella, Streptomyces, and Ochromobactrum, tolerant up to $150 \mathrm{~g} / \mathrm{L}$ of $\mathrm{NaCl}$ [111], and this makes them excellent candidates to alleviate the salt stress of plants. Generally, salinity does not significantly alter soil microbial communities, perhaps due to a sort of buffer effect [112,113]. In some cases, soil microbial diversity was mainly influenced by soil salinity [42]. In the presence of high salinity and scarcity of water, plants are subjected to considerable stress, which leads to numerous adverse effects, including reduced photosynthetic activity, limited assimilation of nutrients, oxidation and consequent deterioration of cell membranes, and dehydration of the plant, which can lead to death. Abiotic stresses, such as drought and salinity, have a strong and severe impact on agriculture, further aggravating the functionality of ecosystem services. The selection of stress-tolerant species and understanding the biochemical mechanisms underlying this tolerance is certainly a way forward. However, undoubtedly, the contribution that PGPR can make in mitigating the damage caused to plants by salinity and drought is the most important [114]. To date, there are many microorganisms isolated from soils, which show interesting properties for promoting plant growth. The search and selection of the best multifunctional PGPR, safe for the environment and humans, is the right way to meet the needs and production needs of agriculture in the world [115].

PGPR can increase the tolerance of plants to salinity, acting primarily through the accumulation of osmolytes, increasing the absorption of nutrients, the nitrogen fixation, the solubilization of $P$ and other essential elements, but similarly with the activity of ACC deaminase, the production of auxins, siderophores, and exopolysaccharides [116].

Furthermore, the regulation implemented by aquaporins whose synthesis is induced by water stress is particularly critical for mitigating the adverse effect of salinity. Aquaporins influence the ability to absorb water, thus maintaining adequate photosynthesis [117]. Several halotolerant bacteria have been isolated from halophilic plants of Salicornia [118] and Suaeda [119], species grown in the desert, saline, and alkaline-saline soils. These halotolerant bacteria can survive in high salt environments by different fielding mechanisms [120]. For example, ion pumps can regulate intracellular ion concentrations, accumulate sugars (i.e., sucrose, trehalose, glycerol), produce exopolysaccharides (EPS), thus creating hydrating biofilms [121].

\subsection{Water Phytodepuration}

Even though our planet has huge water reserves (over $70 \%$ of the entire surface), only $3 \%$ of freshwater is available and accessible. This means that around 3 billion people have no or limited access to water for daily use. The global rise in temperatures is causing the drying up of many rivers, lakes, and aquifers, which can no longer support the various ecosystems and feed the population. Unfortunately, this phenomenon is also accompanied by the problem of pollution and the need to purify contaminated waters before their eventual reuse. Currently, wastewater from purification plants is already widely used in agriculture [122,123].

Therefore, sustainable strategies are increasingly required for better reuse of water. Among these, the constructed wetlands (CW) systems are the ones that, reproducing the natural purification processes of wetlands, represent the best solution (Figure 3). Plants can remove pollutants from water, significantly improving water quality [124]. In drought conditions, salinity or the presence of contaminants, plants tend to minimize metabolism, thus affecting photosynthesis and, consequently, growth. Through the activation of the direct and indirect mechanisms described above, PGPR can favor the growth and development of plants by mitigating and sometimes even abolishing the adverse effects of environmental stresses [125]. The toxic, polluting substances with the most significant impact on human 
health are pharmaceutical products or their metabolites, textile industry residues (i.e., azo dyes), and heavy metals that derive mainly from industrial processes.

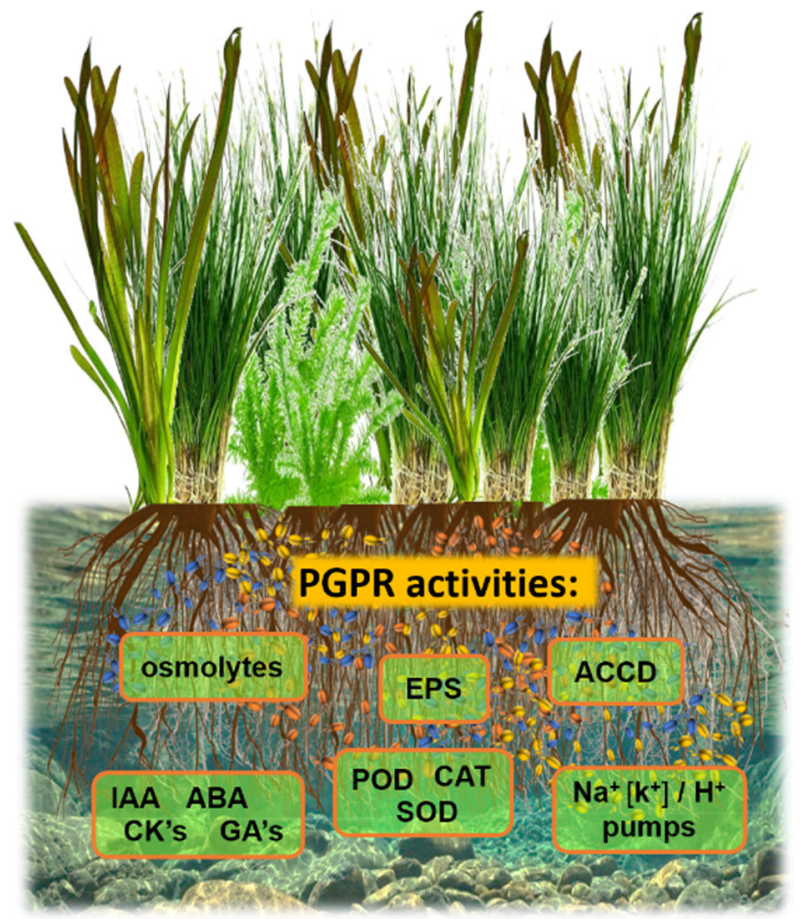

Figure 3. Scheme of a constructed wetland (CW) for a phytodepuration approach. The most critical PGPR activities beneficial to support and to alleviate environmental stresses (salinity, heavy metals, hydrocarbons) are the production of phytohormones, 3-indol acetic acid (IAA), abscisic acid (ABA), cytokines (CK's), gibberellins (GA's) modulating plant physiology; ACC deaminase (ACCD) activity lowering ethylene level; activation of antioxidant enzymes (superoxide dismutase, SOD; catalase, CAT; peroxidase, POD); $\mathrm{Na}^{+}\left(\mathrm{K}^{+}\right) / \mathbf{H}^{+}$pumps regulating ions homeostasis; production of exopolysaccharides (EPS); production of osmolytes (i.e., proline, glycine, betaine) to stabilize protein conformation.

The peculiar properties of PGPR are essential to support the plants used in phytodepuration. The production of IAA, which stimulates the development of the root system, undoubtedly represents a significant advantage in increasing the efficiency of constructed wetlands [126,127].

The degradative activity of the contaminants owned by rhizospheric bacteria and, above all, can be successfully used downstream of the conventional treatments of industrial and municipal wastewater [128]. Furthermore, the polluted matrices of selected microbial inocula in which the presence of the metabolic pathways necessary for the degradation of the pollutants present in the wastewater has been identified, could transform the wastewater into water suitable for irrigation [129].

\section{Conclusions}

The phytoremediation as reclamation approach offers the highest index of environmental sustainability (e.g., minimization of impacts on the environment and human health; reduction of use of energy and non-renewable resources; environmental improvement of the remediated areas). At the same time, phytoremediation is also a purely site-specific technology, and the complex and coordinated interactions between the host plant and the rhizospheric microbial community in response to the structure of the matrix and various environmental stresses produce specific outcomes from time to time. For this reason, the global market requires further progress in terms of technological efficiency, where a better understanding of plant-microorganism interactions, being the basis of assisted phytoremediation, is essential to obtain even higher levels of environmental and economic sustainability. Indeed, the powerful symbiotic connection that plants develop with micro- 
bial physiology is fundamental for the development and growth of plants, especially in conditions of biotic and abiotic stress.

A better and in-depth understanding of the function and interactions of plants and associated microorganisms directly in the matrix of interest can be favored by the adoption of a holistic approach that uses "omic" technologies (metagenomics, metaproteomics, metatranscriptomics, etc.). The combination of these approaches in the presence of persistent contamination by known or by new emerging pollutants could provide new opportunities for phytoremediation.

Author Contributions: Conceptualization, E.F. and G.P.; validation, M.V. and E.F.; investigation, M.V., M.G. and D.F.; resources, G.P. and E.F.; data curation, M.V.; writing-original draft preparation, M.V., D.F. and E.F.; writing-review and editing, M.V. and E.F.; visualization, M.V. and E.F.; supervision, M.V.; project administration, G.P. and E.F.; funding acquisition, E.F. All authors have read and agreed to the published version of the manuscript.

Funding: This research received no external funding.

Institutional Review Board Statement: Not applicable.

Informed Consent Statement: Not applicable.

Data Availability Statement: Data is contained within the present article.

Conflicts of Interest: The authors declare no conflict of interest.

\section{References}

1. Pietrelli, L.; Ferro, S.; Reverberi, A.P.; Vocciante, M. Removal and recovery of heavy metals from tannery sludge subjected to plasma pyro-gasification process. J. Clean. Prod. 2020, 273, 123166. [CrossRef]

2. Vocciante, M.; Meshalkin, V. An accurate inverse model for the detection of leaks in sealed landfills. Sustainability 2020, $12,5598$. [CrossRef]

3. Pietrelli, L.; Ferro, S.; Vocciante, M. Eco-friendly and cost-effective strategies for metals recovery from printed circuit boards. Renew. Sustain. Energy Rev. 2019, 112, 317-323. [CrossRef]

4. Cachada, A.; Rocha-Santos, T.A.P.; Duarte, A.C. Soil and pollution: An introduction to the main issues. In Soil Pollution: From Monitoring to Remediation; Duarte, A.C., Cachada, A., Rocha-Santos, T.A.P., Eds.; Academic Press: Cambridge, MA, USA, 2018 ; pp. 1-28.

5. Puri, N.; Gupta, A.; Mishra, A. Recent advances on nano-adsorbents and nanomembranes for the remediation of water. J. Clean. Prod. 2021, 322, 129051. [CrossRef]

6. Pietrelli, L.; Ferro, S.; Reverberi, A.P.; Vocciante, M. Removal of polyethylene glycols from wastewater: A comparison of different approaches. Chemosphere 2021, 273, 129725. [CrossRef]

7. Alberti, S.; Basciu, I.; Vocciante, M.; Ferretti, M. Experimental and physico-chemical comparison of ZnO nanoparticles' activity for photocatalytic applications in wastewater treatment. Catalysts 2021, 11, 678. [CrossRef]

8. Reverberi, A.P.; Varbanov, P.S.; Vocciante, M.; Fabiano, B. Bismuth oxide-related photocatalysts in green nanotechnology: A critical analysis. Front. Chem. Sci. Eng. 2018, 12, 878-892. [CrossRef]

9. Li, C.; Zhou, K.; Qin, W.; Tian, C.; Qi, M.; Yan, X.; Han, W. A review on heavy metals contamination in soil: Effects, sources, and remediation techniques. Soil Sediment Contam. 2019, 28, 380-394. [CrossRef]

10. Petruzzelli, G.; Pedron, F.; Grifoni, M.; Barbafieri, M.; Rosellini, I.; Pezzarossa, B. Soil remediation technologies towards green remediation strategies. Int. J. Geol. Environ. Eng. 2016, 10, 646-650. [CrossRef]

11. Vocciante, M.; Reverberi, A.P.; Pietrelli, L.; Dovì, V.G. Improved remediation processes through cost-effective estimation of soil properties from surface measurements. J. Clean. Prod. 2017, 167, 680-686. [CrossRef]

12. da Silva, B.M.; Maranho, L.T. Petroleum-contaminated sites: Decision framework for selecting remediation technologies. J. Hazard. Mater. 2019, 378, 120722. [CrossRef] [PubMed]

13. Song, Y.; Kirkwood, N.; Maksimović, Č.; Zhen, X.; O'Connor, D.; Jin, Y.; Hou, D. Nature based solutions for contaminated land remediation and brownfield redevelopment in cities: A review. Sci. Total Environ. 2019, 663, 568-579. [CrossRef] [PubMed]

14. Vocciante, M.; Dovì, V.G.; Ferro, S. Sustainability in electroKinetic remediation processes: A critical analysis. Sustainability 2021, 13, 770. [CrossRef]

15. Reverberi, A.P.; Vocciante, M.; Lunghi, E.; Pietrelli, L.; Fabiano, B. New trends in the synthesis of nanoparticles by green methods CET 2017, 61, 667-672. [CrossRef]

16. Reverberi, A.P.; Varbanov, P.S.; Lauciello, S.; Salerno, M.; Fabiano, B. An eco-friendly process for zerovalent bismuth nanoparticles synthesis. J. Clean. Prod. 2018, 198, 37-45. [CrossRef]

17. Vocciante, M.; Caretta, A.; Bua, L.; Bagatin, R.; Franchi, E.; Petruzzelli, G.; Ferro, S. Enhancements in phytoremediation technology: Environmental assessment including different options of biomass disposal and comparison with a consolidated approach. J. Environ. Manag. 2019, 237, 560-568. [CrossRef] 
18. Vocciante, M.; de Folly D'Auris, A.; Franchi, E.; Petruzzelli, G.; Ferro, S. $\mathrm{CO}_{2}$ footprint analysis of consolidated and innovative technologies in remediation activities. J. Clean. Prod. 2021, 297, 126723. [CrossRef]

19. Pedron, F.; Grifoni, M.; Barbafieri, M.; Petruzzelli, G.; Rosellini, I.; Franchi, E.; Bagatin, R.; Vocciante, M. Applicability of a Freundlich-like model for plant uptake at an industrial contaminated site with a high variable arsenic concentration. Environments 2017, 4, 67. [CrossRef]

20. Pietrini, I.; Grifoni, M.; Franchi, E.; Cardaci, A.; Pedron, F.; Barbafieri, M.; Petruzzelli, G.; Vocciante, M. Enhanced lead phytoextraction by endophytes from indigenous plants. Soil Syst. 2021, 5, 55. [CrossRef]

21. Conte, A.; Chiaberge, S.; Pedron, F.; Barbafieri, M.; Petruzzelli, G.; Vocciante, M.; Franchi, E.; Pietrini, I. Dealing with complex contamination: A novel approach with a combined bio-phytoremediation strategy and effective analytical techniques. J. Environ. Manag. 2021, 288, 112381. [CrossRef]

22. Pedron, F.; Grifoni, M.; Barbafieri, M.; Petruzzelli, G.; Franchi, E.; Samà, C.; Gila, L.; Zanardi, S.; Palmery, S.; Proto, A.; et al. New light on phytoremediation: The use of luminescent solar concentrators. Appl. Sci. 2021, 11, 1923. [CrossRef]

23. Thijs, S.; Sillen, W.; Rineau, F.; Weyens, N.; Vangronsveld, J. Towards an enhanced understanding of plant-microbiome interactions to improve phytoremediation: Engineering the metaorganism. Front. Microbiol. 2016, 7, 341. [CrossRef] [PubMed]

24. Vangronsveld, J.; Herzig, R.; Weyens, N.; Boulet, J.; Adriaensen, K.; Ruttens, A.; Thewys, T.; Vassilev, A.; Meers, E.; Nehnevajova, E.; et al Phytoremediation of contaminated soils and groundwater: Lessons from the field. Environ. Sci. Pollut. Res. Int. 2009, 16, 765-794. [CrossRef] [PubMed]

25. Sessitsch, A.; Kuffner, M.; Kidd, P.; Vangronsveld, J.; Wenzel, W.W.; Fallmann, K.; Puschenreiter, M. The role of plant-associated bacteria in the mobilization and phytoextraction of trace elements in contaminated soils. Soil Biol. Biochem. 2013, 60, 182-194. [CrossRef]

26. Rodriguez, P.A.; Rothballer, M.; Chowdhury, S.P.; Nussbaumer, T.; Gutjahr, C.; Falter-Braun, P. Systems biology of plantmicrobiome interactions. Mol. Plant 2019, 12, 804-821. [CrossRef]

27. Vives-Peris, V.; de Ollas, C.; Gómez-Cadenas, A.; Pérez-Clemente, R.M. Root exudates: From plant to rhizosphere and beyond Plant Cell. Rep. 2020, 39, 3-17. [CrossRef] [PubMed]

28. Correa-García, S.; Pande, P.; Séguin, A.; St-Arnaud, M.; Yergeau, E. Rhizoremediation of petroleum hydrocarbons: A model system for plant microbiome manipulation. Microb. Biotechnol. 2018, 11, 819-832. [CrossRef]

29. Matthews, A.; Pierce, S.; Hipperson, H.; Raymond, B. Rhizobacterial Community Assembly Patterns Vary Between Crop Species Front. Microbiol. 2019, 10, 581. [CrossRef]

30. Guo, B.; Zhang, Y.; Li, S.; Lai, T.; Yang, L.; Chen, J.; Ding, W. Extract from Maize (Zea mays L.): Antibacterial activity of DIMBOA and its derivatives against Ralstonia solanacearum. Molecules 2016, 21, 1397. [CrossRef]

31. Sasse, J.; Martinoia, E.; Northen, T. Feed your friends: Do plant exudates shape the root microbiome? Trends Plant Sci. 2018, 23, 25-41. [CrossRef]

32. Santoyo, G.; Urtis-Flores, C.A.; Loeza-Lara, P.D.; Orozco-Mosqueda, M.D.C.; Glick, B.R. Rhizosphere colonization determinants by Plant Growth-Promoting Rhizobacteria (PGPR). Biology 2021, 10, 475. [CrossRef] [PubMed]

33. Phour, M.; Sehrawat, A.; Sindhu, S.S.; Glick, B.R. Interkingdom signaling in plant-rhizomicrobiome interactions for sustainable agriculture. Microbiol. Res. 2020, 241, 126589. [CrossRef] [PubMed]

34. Dassen, S.; Cortois, R.; Martens, H.; de Hollander, M.; Kowalchuk, G.A.; van der Putten, W.H.; De Deyn, G.B. Differential responses of soil bacteria, fungi, archaea and protists to plant species richness and plant functional group identity. Mol. Ecol. 2017, 26, 4085-4098. [CrossRef] [PubMed]

35. Levy, A.; Conway, J.M.; Dangl, J.L.; Woyke, T. Elucidating bacterial gene functions in the plant microbiome. Cell Host Microbe 2018, 24, 475-485. [CrossRef] [PubMed]

36. Truyens, S.; Weyens, N.; Cuypers, A.; Vangronsveld, J. Bacterial seed endophytes: Genera, vertical transmission and interaction with plants. Environ. Microbiol. Rep. 2015, 7, 40-50. [CrossRef]

37. Truyens, S.; Beckers, B.; Thijs, S.; Weyens, N.; Cuypers, A.; Vangronsveld, J. Cadmium-induced and transgenerational changes in the cultivable and total seed endophytic community of Arabidopsis thaliana. Plant Biol. J. 2015, 18, 376-381. [CrossRef]

38. Thomas, F.; Corre, E.; Cébron, A. Stable isotope probing and metagenomics highlight the effect of plants on uncultured phenanthrene-degrading bacterial consortium in polluted soil. ISME J. 2019, 13, 1814-1830. [CrossRef]

39. Dagher, D.J.; de la Providencia, I.E.; Pitre, F.E.; St-Arnaud, M.; Hijri, M. Plant Identity Shaped Rhizospheric Microbial Communities More Strongly Than Bacterial Bioaugmentation in Petroleum Hydrocarbon-Polluted Sediments. Front. Microbiol. 2019, 10, 2144. [CrossRef]

40. Yergeau, E.; Sanschagrin, S.; Maynard, C.; St-Arnaud, M.; Greer, C.W. Microbial expression profiles in the rhizosphere of willows depend on soil contamination. ISME J. 2014, 8, 344-358. [CrossRef]

41. Grime, J.P. Evidence for the existence of three primary strategies in plants and its relevance to ecological and evolutionary theory. Am. Nat. 1977, 111, 1169-1194. [CrossRef]

42. Santoyo, G.; Moreno-Hagelsieb, G.; del Carmen Orozco-Mosqueda, M.; Glick, B.R. Plant growth-promoting bacterial endophytes Microbiol. Res. 2016, 183, 92-99. [CrossRef] [PubMed]

43. Gkorezis, P.; Daghio, M.; Franzetti, A.; Van Hamme, J.D.; Sillen, W.; Vangronsveld, J. The interaction between plants and bacteria in the remediation of petroleum hydrocarbons: An environmental perspective. Front. Microbiol. 2016, 7, 1836. [CrossRef] [PubMed] 
44. Rohrbacher, F.; St-Arnaud, M. Root exudation: The ecological driver of hydrocarbon rhizoremediation. Agronomy 2016, 6, 19. [CrossRef]

45. Kong, Z.; Glick, B.R. The role of Plant Growth-Promoting Bacteria in metal phytoremediation. Adv. Microb. Physiol. 2017, 71, 97-132. [CrossRef]

46. Giauque, H.; Connor, E.W.; Hawkes, C.V. Endophyte traits relevant to stress tolerance, resource use and habitat of origin predict effects on host plants. New Phytol. 2019, 221, 2239-2249. [CrossRef] [PubMed]

47. Sørensen, J.; Sessitsch, A. Plant-associated bacteria lifestyle and molecular interactions. In Modern Soil Microbiology, 2nd ed.; van Elsas, J.D., Trevors, J.T., Jansson, J.K., Nannipieri, P., Eds.; CRC Press: Boca Raton, FL, USA, 2006; pp. 211-236.

48. Pankievicz, V.C.S.; Irving, T.B.; Maia, L.G.S.; Ané, J. Are we there yet? The long walk towards the development of efficient symbiotic associations between nitrogen-fixing bacteria and non-leguminous crops. BMC Biol. 2019, 17, 99. [CrossRef]

49. Alori, E.T.; Glick, B.R.; Babalola, O.O. Microbial phosphorus solubilization and its potential for use in sustainable agriculture Front. Microbiol. 2017, 8, 971. [CrossRef]

50. Duca, D.R.; Glick, B.R. Indole-3-acetic acid biosynthesis and its regulation in plant-associated bacteria. Appl. Microbiol. Biotechnol. 2020, 104, 8607-8619. [CrossRef]

51. Pavlů, J.; Novák, J.; Koukalová, V.; Luklová, M.; Brzobohatý, B.; Černý, M. Cytokinin at the crossroads of abiotic stress signalling Pathways. Int. J. Mol. Sci. 2018, 19, 2450. [CrossRef]

52. Gupta, S.; Pandey, S. ACC Deaminase Producing Bacteria with Multifarious plant growth promoting traits alleviates salinity stress in french bean (Phaseolus vulgaris) Plants. Front. Microbiol. 2019, 10, 1506. [CrossRef]

53. Radzki, W.; Gutierrez Mañero, F.J.; Algar, E.; Lucas García, J.A.; García-Villaraco, A.; Ramos Solano, B. Bacterial siderophores efficiently provide iron to iron-starved tomato plants in hydroponics culture. Antonie Van Leeuwenhoek 2013, 104, 321-330. [CrossRef] [PubMed]

54. Olanrewaju, O.S.; Glick, B.R.; Babalola, O.O. Mechanisms of action of plant growth promoting bacteria. World J. Microbiol. Biotechnol. 2017, 33, 197. [CrossRef] [PubMed]

55. Hider, R.C.; Kong, X. Chemistry and biology of siderophores. Nat. Prod. Rep. 2010, 27, 637-657. [CrossRef] [PubMed]

56. Saha, M.; Sarkar, S.; Sarkar, B.; Sharma, B.K.; Bhattacharjee, S.; Tribedi, P. Microbial siderophores and their potential applications: A review. Environ. Sci. Pollut. Res. Int. 2016, 23, 3984-3999. [CrossRef] [PubMed]

57. Ma, Y.; Rajkumar, M.; Zhang, C.; Freitas, H. Beneficial role of bacterial endophytes in heavy metal phytoremediation. J. Environ. Manag. 2016, 174, 14-25. [CrossRef]

58. Guo, J.; Muhammad, H.; Lv, X.; Wei, T.; Ren, X.; Jia, H.; Atif, S.; Hua, L. Prospects and applications of plant growth promoting rhizobacteria to mitigate soil metal contamination: A review. Chemosphere 2020, 246, 125823. [CrossRef]

59. Shen, J.; Yuan, L.; Zhang, J.; Li, H.; Bai, Z.; Chen, X.; Zhang, W.; Zhang, F. Phosphorus dynamics: From soil to plant. Plant Physiol. 2011, 156, 997-1005. [CrossRef]

60. Liang, J.; Klingl, A.; Lin, Y.Y.; Boul, E.; Thomas-Oates, J.; Marín, M. A subcompatible rhizobium strain reveals infection duality in Lotus. J. Exp. Bot. 2019, 70, 1903-1913. [CrossRef]

61. Sickerman, N.S.; Hu, Y.; Ribbe, M.W. Nitrogenases. Methods Mol. Biol. 2019, 1876, 3-24. [CrossRef]

62. Aasfar, A.; Bargaz, A.; Yaakoubi, K.; Hilali, A.; Bennis, I.; Zeroual, Y.; Meftah Kadmiri, I. Nitrogen Fixing Azotobacter Species as Potential Soil Biological Enhancers for Crop Nutrition and Yield Stability. Front. Microbiol. 2021, 12, 628379. [CrossRef]

63. Singh, R.K.; Singh, P.; Li, H.B.; Yang, L.T.; Li, Y.R. Soil-Plant-Microbe Interactions: Use of Nitrogen-Fixing Bacteria for Plant Growth and Development in Sugarcane. In Plant-Microbe Interactions in Agro-Ecological Perspectives; Singh, D., Singh, H., Prabha, R., Eds.; Springer: Singapore, 2017; pp. 35-59. [CrossRef]

64. Brewin, N.J. Plant cell wall remodelling in the rhizobium-legume symbiosis. Crit. Rev. Plant Sci. 2004, 23, 293-316. [CrossRef]

65. Luo, J.; Zhou, J.J.; Zhang, J.Z. Aux/IAA gene family in plants: Molecular structure, regulation, and function. Int. J. Mol. Sci. 2018, 19, 259. [CrossRef] [PubMed]

66. Grobelak, A.; Napora, A.; Kacprzak, M. Using plant growth-promoting rhizobacteria (PGPR) to improve plant growth. Ecol. Eng. 2015, 84, 22-28. [CrossRef]

67. Hönig, M.; Plíhalová, L.; Husičková, A.; Nisler, J.; Doležal, K. Role of cytokinins in senescence, antioxidant defence and photosynthesis. Int. J. Mol. Sci. 2018, 19, 4045. [CrossRef]

68. Rizza, A.; Jones, A.M. The makings of a gradient: Spatiotemporal distribution of gibberellins in plant development. Curr. Opin. Plant Biol. 2019, 47, 9-15. [CrossRef]

69. Nett, R.S.; Montanares, M.; Marcassa, A.; Lu, X.; Nagel, R.; Charles, T.C.; Hedden, P.; Rojas, M.C.; Peters, R.J. Elucidation of gibberellin biosynthesis in bacteria reveals convergent evolution. Nat. Chem. Boil. 2017, 13, 69-74. [CrossRef]

70. Glick, B.R. Bacteria with ACC deaminase can promote plant growth and help to feed the world. Microbiol. Res. 2014, 169, 30-39. [CrossRef]

71. del Carmen Orozco-Mosqueda, M.; Glick, B.R.; Santoyo, G. ACC deaminase in plant growth-promoting bacteria (PGPB): An efficient mechanism to counter salt stress in crops. Microbiol. Res. 2020, 235, 126439. [CrossRef]

72. Glick, B.R. Using soil bacteria to facilitate phytoremediation. Biotechnol. Adv. 2010, 28, 367-374. [CrossRef]

73. Kundan, R.; Pant, G.; Jadon, N.; Agrawal, P.K. Plant growth promoting rhizobacteria: Mechanism and current prospective. J. Fertil. Pestic. 2015, 6, 155. [CrossRef] 
74. Suárez-Moreno, Z.R.; Vinchira-Villarraga, D.M.; Vergara-Morales, D.I.; Castellanos, L.; Ramos, F.A.; Guarnaccia, C.; Degrassi, G.; Venturi, V.; Moreno-Sarmiento, N. Plant-Growth promotion and biocontrol properties of three Streptomyces spp. isolates to control bacterial rice pathogens. Front. Microbiol. 2019, 10, 290. [CrossRef] [PubMed]

75. Barahona, E.; Navazo, A.; Martínez-Granero, F.; Zea-Bonilla, T.; Pérez-Jiménez, R.M.; Martín, M.; Rivilla, R. Pseudomonas fluorescens F113 mutant with enhanced competitive colonization ability and improved biocontrol activity against fungal root pathogens. Appl. Environ. Microbiol. 2011, 77, 5412-5419. [CrossRef] [PubMed]

76. Tsegaye, Z.; Gizaw, B.; Tefera, G.; Feleke, A.; Chaniyalew, S.; Alemu, T.; Assefa, F. Isolation and biochemical characterization of Plant Growth Promoting (PGP) bacteria colonizing the rhizosphere of Tef crop during the seedling stage. J. Plant Sci. Phytopathol. 2019, 3, 013-027. [CrossRef]

77. Abatenh, E.; Gizaw, B.; Tsegaye, Z.; Wassie, M. The role of microorganisms in bioremediation-A Review. Open J. Environ. Biol. 2017, 2, 38-46. [CrossRef]

78. Tyagi, M.; da Fonseca, M.M.R.; de Carvalho, C. Bioaugmentation and biostimulation strategies to improve the effectivenesss of bioremediation processes. Biodegradation 2011, 22, 231-241. [CrossRef] [PubMed]

79. Urana, R.; Dahiya, A.; Sharma, P.; Singh, N. Effects of plant growth promoting rhizobacteria on phytoremediation of phenanthrene contaminated sodic soil. Polycycl. Aromat. Comp. 2019, 41, 1020-1029. [CrossRef]

80. Nie, M.; Wang, Y.; Yu, J.; Xiao, M.; Jiang, J.; Fang, C.; Chen, J.; Li, B. Understanding plant-microbe interactions for phytoremediation of petroleum-polluted soil. PLOS ONE 2011, 6, e17961. [CrossRef]

81. Franchi, E.; Agazzi, G.; Rolli, E.; Borin, S.; Chiaberge, S.; Conte, A.; Filtri, P.; Pedron, F.; Rosellini, I.; Barbafieri, M.; et al. Exploiting hydrocarbon-degrader indigenous bacteria for bioremediation and phytoremediation of a multi-contaminated soil. Chem. Eng. Technol. 2016, 39, 1676-1684. [CrossRef]

82. Lumactud, R.; Shen, S.Y.; Lau, M.; Fulthorpe, R. Bacterial endophytes isolated from plants in natural oil seep soils with chronic hydrocarbon contamination. Front. Microbiol. 2016, 7, 755. [CrossRef]

83. Marchut-Mikolajczyk, O.; Drożdżyński, P.; Pietrzyk, D.; Antczak, T. Biosurfactant production and hydrocarbon degradation activity of endophytic bacteria isolated from Chelidonium majus L. Microb. Cell Fact. 2018, 17, 171. [CrossRef]

84. DalCorso, G.; Fasani, E.; Manara, A.; Visioli, G.; Furini, A. Heavy metal pollutions: State of the art and innovation in phytoremediation. Int. J. Mol. Sci. 2019, 20,3412. [CrossRef] [PubMed]

85. Mishra, J.; Singh, R.; Arora, N.K. Alleviation of heavy metal stress in plants and remediation of soil by rhizosphere microorganisms. Front Microbiol. 2017, 8, 1706. [CrossRef] [PubMed]

86. Liu, W.; Wang, Q.; Wang, B.; Hou, J.; Luo, Y.; Tang, C.; Franks, A.E. Plant growth-promoting rhizobacteria enhance the growth and Cd uptake of Sedum plumbizincicola in a Cd-contaminated soil. J. Soils Sediments 2015, 15, 1191-1199. [CrossRef]

87. Guo, J.; Chi, J. Effect of Cd-tolerant plant growth-promoting rhizobium on plant growth and Cd uptake by Lolium multiflorum Lam. and Glycine max (L.) Merr. in Cd-contaminated soil. Plant Soil 2014, 375, 205-214. [CrossRef]

88. Moreira, H.; Marques, A.P.; Franco, A.R.; Rangel, A.O.; Castro, P.M. Phytomanagement of Cd-contaminated soils using maize (Zea mays L.) assisted by plant growth-promoting rhizobacteria. Environ. Sci. Pollut. Res. Int. 2014, 21, 9742-9753. [CrossRef]

89. Ju, W.; Liu, L.; Fang, L.; Cui, Y.; Duan, C.; Wu, H. Impact of co-inoculation with plant-growth-promoting rhizobacteria and rhizobium on the biochemical responses of alfalfa-soil system in copper contaminated soil. Ecotoxicol. Environ. Saf. 2019, 167, 218-226. [CrossRef]

90. Korir, H.; Mungai, N.W.; Thuita, M.; Hamba, Y.; Masso, C. Co-inoculation effect of rhizobia and plant growth promoting rhizobacteria on common bean growth in a low phosphorus soil. Front. Plant Sci. 2017, 8, 141. [CrossRef]

91. Raklami, A.; Oufdou, K.; Tahiri, A.I.; Mateos-Naranjo, E.; Navarro-Torre, S.; Rodríguez-Llorente, I.D.; Meddich, A.; RedondoGómez, S.; Pajuelo, E. Safe Cultivation of Medicago sativa in metal-polluted soils from semi-arid regions assisted by heat- and metallo-resistant PGPR. Microorganisms 2019, 7, 212. [CrossRef]

92. Praburaman, L.; Park, S.H.; Cho, M.; Lee, K.; Ko, J.; Han, S.; Lee, S.; Kamala-Kannan, S.; Oh, B. Significance of diazotrophic plant growth-promoting Herbaspirillum sp. GW103 on phytoextraction of Pb and Zn by Zea mays L. Environ. Sci. Pollut. Res. Int. 2017, 24, 3172-3180. [CrossRef]

93. Abbaszadeh-Dahaji, P.; Baniasad-Asgari, A.; Hamidpour, M. The effect of Cu-resistant plant growth-promoting rhizobacteria and EDTA on phytoremediation efficiency of plants in a Cu-contaminated soil. Environ. Sci. Pollut. Res. Int. 2019, 26, 31822-31833. [CrossRef]

94. Hamidpour, M.; Nemati, H.; Abbaszadeh Dahaji, P.; Reza Roosta, H. Effects of plant growth-promoting bacteria on EDTA-assisted phytostabilization of heavy metals in a contaminated calcareous soil. Environ. Geochem. Health 2020, 42, 2535-2545. [CrossRef] [PubMed]

95. Franchi, E.; Petruzzelli, G. Phytoremediation and the key role of PGPR. In Advances in PGPR Research; Singh, H.B., Sarma, B.K., Keswani, C., Eds.; CABI: Wallingford, UK, 2017; pp. 306-329.

96. Franchi, E.; Cosmina, P.; Pedron, F.; Rosellini, I.; Barbafieri, M.; Petruzzelli, G.; Vocciante, M. Improved arsenic phytoextraction by combined use of mobilizing chemicals and autochthonous soil bacteria. Sci. Total Environ. 2019, 655, 328-336. [CrossRef] [PubMed]

97. Ullah, A.; Heng, S.; Munis, M.F.H.; Fahad, S.; Yang, X. Phytoremediation of heavy metals assisted by plant growth promoting (PGP) bacteria: A review. Environ. Exp. Bot. 2015, 117, 28-40. [CrossRef]

98. Enebe, M.C.; Babalola, O.O. The influence of plant growth-promoting rhizobacteria in plant tolerance to abiotic stress: A survival strategy. Appl. Microbiol. Biotechnol. 2018, 102, 7821-7835. [CrossRef] [PubMed] 
99. Misra, V.; Solomon, S.; Mall, A.K.; Prajapati, C.P.; Hashem, A.; Abd Allah, E.F.; Ansari, M.I. Morphological assessment of water stressed sugarcane: A comparison of waterlogged and drought affected crop. Saudi J. Biol. Sci. 2020, 27, 1228-1236. [CrossRef] [PubMed]

100. Niu, X.; Song, L.; Xiao, Y.; Ge, W. Drought-tolerant plant growth-promoting rhizobacteria associated with foxtail millet in a semi-arid agroecosystem and their potential in alleviating drought stress. Front. Microbiol. 2018, 8, 2580. [CrossRef]

101. Ilyas, N.; Mumtaz, K.; Akhtar, N.; Yasmin, H.; Sayyed, R.Z.; Khan, W.; El Enshasy, H.A.; Dailin, D.J.; Elsayed, E.A.; Ali, Z. Exopolysaccharides producing bacteria for the amelioration of drought stress in wheat. Sustainability 2020, 12, 8876. [CrossRef]

102. Rahdari, P.; Hoseini, S.M. Drought stress, a review. Int. J. Agron. Plant Prod. 2012, 3, 443-446.

103. Vurukonda, S.S.; Vardharajula, S.; Shrivastava, M.; SkZ, A. Enhancement of drought stress tolerance in crops by plant growth promoting rhizobacteria. Microbiol. Res. 2016, 184, 13-24. [CrossRef]

104. Koevoets, I.T.; Venema, J.H.; Elzenga, J.T.; Testerink, C. Roots withstanding their environment: Exploiting root system architecture responses to abiotic stress to improve crop tolerance. Front. Plant Sci. 2016, 7, 1335. [CrossRef]

105. Comas, L.H.; Becker, S.R.; Cruz, V.M.; Byrne, P.F.; Dierig, D.A. Root traits contributing to plant productivity under drought. Front. Plant Sci. 2013, 4, 442. [CrossRef] [PubMed]

106. Gagné-Bourque, F.; Bertrand, A.; Claessens, A.; Aliferis, K.A.; Jabaji, S. Alleviation of drought stress and metabolic changes in timothy (Phleum pratense L.) colonized with Bacillus subtilis B26. Front. Plant Sci. 2016, 7, 584. [CrossRef] [PubMed]

107. Schirawski, J.; Perlin, M.H. Plant-microbe interaction 2017-The good, the bad and the diverse. Int. J. Mol. Sci. 2018, 19, 1374 [CrossRef] [PubMed]

108. Ayyam, V.; Palanivel, S.; Chandrakasan, S. Approaches in land degradation management for productivity enhancement. In Coastal Ecosystems of the Tropics—Adaptive Management; Ayyam, V., Palanivel, S., Chandrakasan, S., Eds.; Springer: Singapore, 2019; pp. 463-491.

109. Toro, G.; Pimentel, P.; Salvatierra, A. Effective categorization of tolerance to salt stress through clustering Prunus Rootstocks according to their physiological performances. Horticulturae 2021, 7, 542. [CrossRef]

110. Flowers, T.J.; Colmer, T.D. Plant salt tolerance: Adaptations in halophytes. Ann. Bot. 2015, 115, 327-331. [CrossRef] [PubMed]

111. Zhang, S.; Fan, C.; Wang, Y.; Xia, Y.; Xiao, W.; Cui, X. Salt-tolerant and plant-growth-promoting bacteria isolated from high-yield paddy soil. Can. J. Microbiol. 2018, 64, 968-978. [CrossRef]

112. Yaish, M.W.; Al-Harrasi, I.; Alansari, A.S.; Al-Yahyai, R.; Glick, B.R. The use of high throughput DNA sequence analysis to assess the endophytic microbiome of date palm roots grown under different levels of salt stress. Int. Microbiol. 2016, 19, 143-155. [CrossRef]

113. Yaish, M.W.; Al-Lawati, A.; Jana, G.A.; Patankar, H.V.; Glick, B.R. Impact of soil salinity on the structure of the bacterial endophytic community identified from the roots of caliph medic (Medicago truncatula). PLoS ONE 2016, 11, e0159007. [CrossRef]

114. Ma, Y.; Dias, M.C.; Freitas, H. Drought and Salinity Stress Responses and Microbe-Induced Tolerance in Plants. Front. Plant Sci. 2020, 11, 591911. [CrossRef]

115. Otlewska, A.; Migliore, M.; Dybka-Stępień, K.; Manfredini, A.; Struszczyk-Świta, K.; Napoli, R.; Białkowska, A.; Canfora, L.; Pinzari, F. When Salt Meddles Between Plant, Soil, and Microorganisms. Front. Plant Sci. 2020, 11, 553087. [CrossRef]

116. Saghafi, D.; Delangiz, N.; Lajayer, B.A.; Ghorbanpour, M. An overview on improvement of crop productivity in saline soils by halotolerant and halophilic PGPRs. 3 Biotech 2019, 9, 261. [CrossRef] [PubMed]

117. Qin, S.; Liu, Y.; Han, Y.; Xu, G.; Wan, S.; Cui, F.; Li, G. Aquaporins and their function in root water transport under salt stress conditions in Eutrema salsugineum. Plant Sci. 2019, 287, 110199. [CrossRef] [PubMed]

118. Mathew, B.T.; Torky, Y.; Amin, A.; Mourad, A.I.; Ayyash, M.M.; El-Keblawy, A.; Hilal-Alnaqbi, A.; AbuQamar, S.F.; El-Tarabily, K.A. Halotolerant marine rhizosphere-competent actinobacteria promote Salicornia bigelovii growth and seed production using seawater irrigation. Front. Microbiol. 2020, 11, 552. [CrossRef] [PubMed]

119. Alishahi, F.; Alikhani, H.A.; Khoshkholgh-Sima, N.A.; Etesami, H. Mining the roots of various species of the halophyte Suaeda for halotolerant nitrogen-fixing endophytic bacteria with the potential for promoting plant growth. Int. Microbiol. 2020, 23, 415-427. [CrossRef] [PubMed]

120. Etesami, H.; Beattie, G.A. Plant-microbe interactions in adaptation of agricultural crops to abiotic stress conditions. In Probiotics and Plant Health; Kumar, V., Kumar, M., Sharma, S., Prasad, R., Eds.; Springer: Singapore, 2017; pp. 163-200.

121. Qin, Y.; Druzhinina, I.S.; Pan, X.; Yuan, Z. Microbially mediated plant salt tolerance and microbiome-based solutions for saline agriculture. Biotechnol. Adv. 2016, 34, 1245-1259. [CrossRef]

122. Molden, D. Water for Food Water for Life: A Comprehensive Assessment of Water Management in Agriculture; Routledge: Oxfordshire, UK, 2013.

123. Garner, E.; Zhu, N.; Strom, L.; Edwards, M.; Pruden, A. A human exposome framework for guiding risk management and holistic assessment of recycled water quality. Environ. Sci. Water Res. Technol. 2016, 2, 580-598. [CrossRef]

124. Carvalho, P.N.; Arias, C.; Brix, H. Constructed wetlands for water treatment: New developments. Water 2017, 9, 397. [CrossRef]

125. Riva, V.; Terzaghi, E.; Vergani, L.; Mapelli, F.; Zanardini, E.; Morosini, C.; Raspa, G.; Di Guardo, A.; Borin, S. Exploitation of rhizosphere microbiome services. In Methods in Rhizosphere Biology Research; Reinhardt, D., Sharma, A., Eds.; Springer: Singapore, 2019; pp. 105-132. [CrossRef]

126. Rajkumar, M.; Sandhya, S.; Prasad, M.N.V.; Freitas, H. Perspectives of plant associated microbes in heavy metal phytoremediation. Biotechnol. Adv. 2012, 30, 1562-1574. [CrossRef] 
127. Backer, R.; Rokem, J.S.; Ilangumaran, G.; Lamont, J.; Praslickova, D.; Ricci, E.; Subramanian, S.; Smith, D.L. Plant GrowthPromoting Rhizobacteria: Context, mechanisms of action, and roadmap to commercialization of biostimulants for sustainable agriculture. Front Plant Sci. 2018, 23, 1473. [CrossRef] [PubMed]

128. Borruso, L.; Esposito, A.; Bani, A.; Cicazzo, S.; Papa, M.; Zerbe, S.; Brusetti, L. Ecological diversity of sediment rhizobacteria associated with Phragmites australis along a drainage canal in the Yellow River watershed. J. Soils Sediments 2017, 17, 253-265. [CrossRef]

129. Riva, V.; Riva, F.; Vergani, L.; Crotti, E.; Borin, S.; Mapelli, F. Microbial assisted phytodepuration for water reclamation: Environmental benefits and threats. Chemosphere 2020, 241, 124843. [CrossRef] [PubMed] 